\title{
KOMBUCHA TEA: A STUDY ON THE HALAL OF FERMENTED DRINKS
}

\author{
Dody Riswanto ${ }^{1} \&$ Firman Rezaldi ${ }^{2}$ \\ Guidance \& Counseling, Mathla'ul Anwar University ${ }^{1}$ \\ Pharmacy Study Program, Mathla'ul Anwar University ${ }^{2}$ \\ Correspondence Author: ronaldody32@gmail.com
}

\begin{abstract}
Kombucha is a fermented beverage made from tea and sugar. Kombucha has benefits for the health of the body, this is due to various kinds of content including antioxidants, antibacterial, intestinal detoxification, lowering blood pressure and increasing body immunity. Kombucha is a drink that contains alcohol content at the end of the fermentation process. This is problematic because the majority of Indonesian consumers are Muslims who require halal food standards based on the regulations of the Indonesian Ulema Council (MUI). The research method used is a laboratory test with a treatment design that is designed based on chemical test procedures. The conclusion of the study is that based on the results of tests conducted at the health laboratory in the city of Tangerang, the results of the ethanol/alcohol content of 0.055 percent in kombucha drinks. Thus the test results have met the MUI regulations where fermented drinks must be below 0.5 percent to be declared a halal drink.
\end{abstract}

Keywords: Kombucha, Fermentation, Health, Alcohol, Halal.

Abstrak: Kombucha adalah minuman hasil fermentasi cairan teh dan gula. Kombucha memiliki manfaat terhadap kesehatan tubuh, hal itu dikarenakan berbagai macam kandungan diantaranya sebagai antioksidan, antibakteri, detoksifikasi usus, menurunkan tekanan darah dan meningkatkan imunitas tubuh. Kombucha adalah minuman yang menyisakan kandungan kadar alkohol pada hasil akhir proses fermentasi. Hal tersebut bermasalah karena mayoritas konsumen Indonesia adalah muslim yang memerlukan standar kehalalan pangan berdasarkan regulasi Majelis Ulama Indonesia (MUI). Metode penelitian yang digunakan adalah uji laboratorium dengan desain perlakuan yang dirancang berdasarkan prosedur uji kimia. Kesimpulan penelitian adalah berdasarkan hasil tes yang dilakukan di laboratorium kesehatan daerah kota Tangerang didapatkan hasil kandungan etanol/alkohol sebesar 0.055 persen pada minuman kombucha. Dengan demikian hasil tes tersebut telah memenuhi regulasi ketentuan MUI dimana minuman fermentasi harus dibawah 0.5 persen agar dinyatakan sebagai minuman yang halal.

Kata Kunci: Kombucha, Fermentasi, Kesehatan, Alkohol, Halal.

\section{INTRODUCTION}

Kombucha is a fermented beverage product that contains a number of vitamins, minerals, enzymes, and organic acids. Kombucha tea is a traditional beverage product produced by fermenting a solution of tea and sugar using a kombucha starter culture (Acetobacter xylinum and several types of yeast). Kombucha is beneficial for health, among others, as an antioxidant, antibacterial, improving intestinal microflora, increasing body resistance and lowering blood pressure (Aditiwati \& Kusnadi, 2003). 
Kombucha is a fermented beverage made from tea and sugar. Kombucha fermentation takes place through the activity of bacteria and yeast. Kombucha is very useful for the human body. Some of the benefits of kombucha include being an antioxidant, antibacterial, improving intestinal microflora, increasing body resistance and lowering blood pressure (Suhardini et al, 2016).

Kombucha is made using a substrate of 4 different tea variants, namely green tea, black tea, white tea, and oolong tea. The four basic tea types were compared before and after fermentation. The final result after fermentation, in general, experienced changes that tended to be the same, namely experiencing a change in color to become lighter. The longer the fermentation time, the further the degree of color change in kombucha drinks (Khaerah \& Akbar, 2019).

Different types of tea will give Kombucha different colors. If the tea used has a darker color, during the fermentation process SCOBY will also look darker. The change in color of SCOBY to dark is also caused by yeast that sticks to the SCOBY area and looks like hanging threads and forms brown or yellow spots so that the appearance is darker. Then, the sugar used in the process of making green tea and black tea kombucha also affects the color change in SCOBY. If the sugar used is yellow, SCOBY will also follow the color of the solution produced by kombucha (Crum and Alex, 2016).

Kombucha fermentation time is between 8-12 days at 18-2OC, while at higher temperatures the fermentation takes a shorter time. In general, high climates (22-260C) ferment kombucha for 4-6 days. The duration of kombucha fermentation affects the physical, chemical, and organoleptic qualities of kombucha (Nainggolan, 2009).

Fermentation that occurs in the manufacture of kombucha tea is the activity of microorganisms found in the starter culture of kombucha. SCOBY (Symbiotic culture of bacteria and yeasts) is a mixed culture containing bacteria and yeast (Wistiana and Zubaidah, 2015). The mixed culture is divided into two parts, namely the liquid form and the biofilm that floats in it (Chakravorty, et al., 2016).

In Mushrooms (SCOBY) there are bacteria and yeast which are important components for fermentation. Bacteria and yeast are wrapped by a thin permeable membrane (Gadela et al, 2016). The bacteria that play a role in making kombucha are lactic acid bacteria and acetic acid bacteria.

The components produced during fermentation include ethanol, acetic acid and glucuronic acid, phenolic acid, lactic acid, B vitamins and enzymes. In kombucha, there are two types of fermentation processes, namely alcoholic fermentation and acetic acid fermentation. This happens because the yeast contained in kombucha symbiotic culture will remodel sugar into alcohol, while the alcohol that has been formed will be oxidized by lactic and acetic acid bacteria to acetic acid. 
The fermentation process begins with the breakdown of sucrose into glucose and fructose by yeast activity which requires invertase enzymes (Wulandari, 2018). Furthermore, yeast converts glucose from hydrolysis into ethanol and $\mathrm{CO} 2$ then reacts with water to form carbonic acid.

The next stage is alcoholic fermentation, namely yeast will degrade hexose (glucose, fructose) through glycolysis into pyruvic acid. Furthermore, pyruvic acid is carboxylated by the pyruvate decarboxylase enzyme to acetaldehyde and $\mathrm{CO} 2$. Acetaldehyde is converted into ethanol by the enzyme alcohol dehydrogenase (Mehta, et al., 2012). After alcohol is produced, acetic acid fermentation immediately occurs, acetic acid bacteria will convert alcohol into acetic acid aerobically. Ethanol is converted to acetaldehyde by the alcohol dehydrogenation enzyme. Acetaldehyde is oxidized to acetyl CoA by the enzyme aldehyde dehydrogenase. Furthermore, acetyl CoA is converted to acetyl-phosphate by the enzyme phosphotransacetylase. Acetyl-phosphate is dephosphorylated to acetic acid by the acetic kinase enzyme (Mehta et al., 2012).

Kombucha has a sour taste. This is caused by the role of bacteria that cause the appearance of a sour taste in kombucha. The result of fermentation from bacteria causes the characteristic taste of kombucha to be sour or sour (Soto et al, 2018). Sour taste is also influenced by the amount of sugar used, the length of time for fermentation, and room temperature. Lee (2014) stated that, slightly sour to very sour taste in tea depends on the amount of sugar used, fermentation time, and temperature. The total acid in kombucha can increase depending on the treatment given during the fermentation process.

According to Wistiana and Zubaidah (2015), total acid will increase along with the length of fermentation time. In line with this study, Jayabalan, et al., (2007) also found the results that organic acids in the kombucha fermentation system will increase as the fermentation time increases. In green tea samples, the amount of organic acid reached its maximum value on the 15th day of fermentation. This is because during the fermentation process, yeasts and bacteria metabolize sucrose and produce a number of organic acids such as acetic acid, gluconic acid, and glucuronic acid, thereby increasing levels of organic acids. So the higher the organic acid contained in kombucha, the higher the total acid. This is due to the longer the fermentation time, the more acetic acid formed as a result of the metabolism of Acetobacter Xylinum. The longer the fermentation, the more acidic the fermentation will be.

According to Essawet, et al (2015) as the end result of fermentation, in kombucha drinks other compounds will be found besides the main compound, namely sugar, ethyl gluconate, oxalate, saccharate, lactate, 5-ketogluconic acid, 2,5-ketogluconic acid, watersoluble vitamins (B1, B6, B12, C), tea components such as catechins, theaflavins, flavonols, etc. and hydrolytic enzymes.

The content of kombucha which contains a number of compounds that contain nutritional value provides health effects for the human body. On the other hand, there is a small amount of alcohol in the final product of kombucha fermentation, this makes kombucha 
not 100 percent safe to consume. This is because the majority of consumers in Indonesia are Muslims and the legality of halal food is an obligation.

The critical point of halal kombucha drinks is the main focus so that it can be consumed by Indonesian Muslim consumers who make up the majority of the population. The determination of halal and haram for a food and beverage product is based on the fatwa regulation of the Indonesian Ulema Council (MUI) which regulates the standards of how halal a food product is.

\section{METHOD}

The research method used is a laboratory test with a treatment design as follows:

\begin{tabular}{|l|l|l|}
\hline Sample type & Fermentation time & Chemical test \\
\hline P1 & R1 & T1 \\
\hline
\end{tabular}

Information:

P1 = Black Tea Bag

$\mathrm{R} 1=7-8$ days

$\mathrm{T} 1=$ Alcohol Test

This research was conducted in Pandeglang Banten. The sample used was brand X black teabags. The main tools and materials used were black tea bags, topless glass, cloth napkins, medium/large rubber bands, sugar, clean water, SCOBY microbial culture, refrigerators, and other materials. - sterile materials from bacterial contamination or harmful chemical substances. Black tea bags were purchased with the standard MUI halal logo on the tea packaging, and SCOBY microbial cultures were purchased online.

\section{RESULT AND DISCUSSION}

Making kombucha with sample P1 (black tea) is done with ingredients, namely 1-3 liters of clean water, 1-3 ounces of sugar, and SCOBY kombucha starter. The tools needed are a pan, topless glass, cloth napkins, large rubber rope. The kombucha process begins with making sweet tea concentrate by boiling 1-2 liters of clean water with a temperature between 70-80 degrees. Then add black tea, cover the pot tightly, let stand for 3-5 minutes or until the dark color of the tea appears. Remove the tea and add the sugar, stir until the sugar is completely melted.

Mix 1-2 liters of room temperature water with tea concentrate into the topless, the temperature of the tea must be cold or at least warm not too hot. Then add the kombucha starter (vinegar and SCOBY) and stir gently. Cover the glass topless with a clean napkin to avoid dust contamination, ants, and fruit flies do not land on the topless but there is still an air gap that enters, do not close it airtight because the kombucha fermentation process requires air to enter. Tie the cloth napkin with string or a medium/large rubber band tightly and neatly. 
Topless glass is placed in a room that has good air circulation, in this case it is placed in a room that is being tested as an experimental laboratory located in Menes, Pandeglang Banten. During the fermentation process, the room should not be exposed to direct sunlight. Then the fermentation process lasts for 7-8 days, during the fermentation process, the container should not be shaken, moved frequently, or moved, the room must be clean and sterile, no dust, cigarette smoke, and strong odors, keep the room away from the kitchen, burning fires, and also trash cans.

The experiment of the research team in the laboratory rooms failed when moving the topless kombucha to another room. Kombucha was contaminated so that the fermentation process failed and the research team decided to dispose of the remaining contaminated kombucha. Based on this, the research team concluded that during the kombucha fermentation process, moving or shifting topless kombucha to another room is fatal because kombucha is very susceptible to contamination or contamination from air, dust, smoke, pungent odors, and others.

\section{MUI Halal Product Terms}

The provisions of the fatwa of the Indonesian Ulema Council (MUI) Number 10 of 2018 concerning food and beverage products containing alcohol/ethanol states that the use of alcohol/ethanol from non-khamr industrial products (either the result of chemical synthesis or the result of non-khamr fermentation industry) for legal beverage products permissible, if medically harmless and as long as the alcohol/ethanol $(\mathrm{C} 2 \mathrm{H} 5 \mathrm{OH})$ content in the final product is less than $0.5 \%$. The MUI explains that fermented beverage products containing at least $0.5 \%$ alcohol/ethanol are haraam. Fermented beverage products containing less than $0.5 \%$ alcohol/ethanol are legally halal if they are not medically harmful.

Based on the reference to the MUI fatwa regarding halal standards for food/beverage products, it can be concluded that fermented beverage products containing at least $0.5 \%$ alcohol are haraam and if it is less than $0.5 \%$ then the law is halal if medically it is not dangerous. Kombucha is a fermented drink that contains alcohol in it and has health benefits, meaning that if laboratory testing of kombucha alcohol is proven to have an alcohol content below 0.5 percent, then the kombucha drink is declared halal according to MUI standards because until now there has been no valid research stating that kombucha medically harmful to the body, and research that supports kombucha has many health benefits and benefits.

The results of the kombucha alcohol test were carried out at the UPT Regional Health Laboratory (Labkesda) Tangerang city with the result that the ethanol/alcohol content was 0.055 percent. Thus the test results prove validly that the fermented kombucha drink meets the MUI regulation, which is below 0.5 percent, even the alcohol content is very low, which is below 0.1 percent. Based on the results of these tests where the alcohol content is very low, namely below 0.1 percent with details of 0.055 percent, it can be concluded that the fermented kombucha drink made has met MUI halal standards and can be consumed by Muslim consumers safely. 


\section{CONCLUSION}

Kombucha is a fermented beverage between tea and sugar made by a microbial culture starter called SCOBY. Kombucha is made using black tea samples with the halal logo. Kombucha has health benefits, but this drink contains alcohol content in it, therefore it is necessary to do alcohol testing so that kombucha drinks can be safely consumed by Muslim consumers. Based on the results of tests conducted at the Labkesda Tangerang city, the results showed that the ethanol/alcohol content was 0.055 percent. Thus the test results have met the MUI regulations where fermented drinks must be below 0.5 percent to be declared a halal drink.

\section{REFERENCES}

Aditiwati \& Kusnadi. (2003). Kultur Campuran dan Faktor Lingkungan Mikroorganisme yang berperan dalam Fermentasi Tea Cider. Jurnal Sains dan Teknologi ITB. Bandung.

Chakravorty, S. et al. (2016). Kombucha Tea Fermentation : Microbial And Biochemical Dynamics. International Journal of Food Microbiology. Vol. 220 : 63-72

Crum, Hannah \& Alex LaGory. (2016). The Big Book of Kombucha: Brewing, Flavoring, and Enjoying the Health Benefits of Fermented Tea. USA: Storey Publishing.

Essawet, N.A., et al. (2015). Pholyphenols and Antioxidant Activities of Kombucha Beverage Ennriched with Coffeberry Extract. Chem. Ind. Chem. Eng. Q. Vol. 1(3) : 399-409.

Gedela, M., Potu, K.C., Gali, V.L., Alyamany, K., Jha, K.L. (2016). A Case of Hepatotoxicity Related to Kombucha Tea Consumption. Journal South Dakota Medicine. Vol. 69(1), 26-28.

Indokombucha. (2011). Cara Membuat Teh Kombucha. https://indokombucha.com/caramembuat-teh-kombucha/.

Jayabalan, R., S. Marimuthu \& K. Swaminathan. (2007). Changes in Content of Organic Acids and Tea Polyphenols During Kombucha Tea Fermentation. Food Chemistry. Vol. 107, 392-398.

Khaerah, A., Akbar, F. (2019). Aktivitas Antioksidan Teh Kombucha dari Beberapa Varian Teh yang Berbeda. Prosiding Seminar Nasional LP2M UNM (472-476). Malang : UNM ISBN: 978-623-7496-14-4.

Lee, S. (2014). Kombucha Revolution. United States: Ten Speed Press.

Mehta, B., M. Afaf Kamal-Edin, R. Z. Iwanski. (2012). Fermentation Effects on Food Properties. Boca Raton. United States. CRC Press Taylor \& Francis Group.

MUI. (2018). Fatwa Majelis Ulama Indonesia Nomor 10 Tahun 2018 Tentang Produk Makanan dan Minuman yang Mengandung Alkohol/Etanol. 


\section{IJMA: International Journal Mathla'ul Anwar of Halal Issues \\ Volume 1 Number 2: September 2021}

e-ISSN: 2775-6157

p-ISSN: 2807-2952

Nainggolan, J. (2009). Kajian Pertumbuhan Bakteri Acetobacter sp. Dalam Kombucha-Rosela Merah (Hibiscus Sabdariffa) Pada Kadar Gula dan Lama Fermentasi Yang Berbeda. Tesis. Universitas Sumatra Utara: Medan.

Soto, S.A.V., Beaufort, S., Bouajila, J., Souchard, J.P., Taillandier, P. (2018). Understanding Kombucha Tea Fermentation: A Review. Journal of Food Science. Vol. 83(3), 580-588.

Suhardini, Prasis N., dan Elok Zubaidah. (2016). Studi Aktivitas Antioksidan Kombucha Dari Berbagai Jenis Daun Selama Fermentasi. Jurnal Pangan dan Agroindustri. Vol. 4(1) : 221229.

Wistiana, D. \& Zubaidah, E. (2015). Karakteristik Kimiawi Dan Mikrobiologis Kombucha Dari Berbagai Daun Tinggi Fenol Selama Fermentasi. Jurnal Pangan dan Agroindustri. Vol. 3 (4), 1446-1457.

Wulandari, A. (2018). Pengaruh Lama Waktu Fermentasi Kombucha Teh Hijau Daun Jati (Tectona grandis) terhadap Kadar Tanin Total dan Total Asam Tertitrasi (TAT). Skripsi. Universitas Sanata Dharma. Yogyakarta. 